\title{
THE DISSOLUTION OF THE FINANCIAL STATE
}

\author{
Simon Mouatt: Senior Lecturer in Economics \\ Southampton Solent University \\ simon.mouatt@solent.ac.uk \\ May 2009
}

\section{INTRODUCTION}

Which individuals, or entities, control the issue and operation of modern money? In the popular conception both these matters are the responsibility of the monetary authorities - the state. Yet, in the four decades since Miliband's "The State in Capitalist Society", we have experienced a reduction in the scope and size of the state generally. Does this extend to a diminishing state-role in the national monetary system? Whilst some thinkers, such as Killick, have outlined the existence of restricted (fiscal and monetary) policy autonomy, as a consequence of international capital flows, privatisation and foreign corporate investment, far less discussion has taken place regarding the existence and impact of the increasing private control of money-creation and money-value (Killick 1995). This is despite monetary debates, since the classical period, on topics as diverse as convertibility, neutrality or endogeneity.

Furthermore, what about the creation and operation of international monies? The dollar remains the key currency for payments and reserves yet, successful currency competition (greater usage and value) can lead to significant benefits for a nation and/or its financial institutions (Cohen 1998). Has the relative decline of the financial state led to an increased private ability to manipulate currency and, by implication, alter the international balance of power? Given that the control of money resources is a key source of social power, the question would appear to be important.

This paper examines the erosion of (financial) state-sovereignty from a Marxian perspective and argues that the state, which is viewed (in line with Miliband) as an extension of industrial capital interests, has actively participated in these processes. The paper then explores who (or what) might have gained power at the expense of the state or, whether capability has simply evaporated. It could be that the private banking infrastructure, or corporate production structure (or some combination of the two), has gained capabilities. Yet, if power has been gained by bankers and non-financial corporations, how do these two separate entities interact and what are their particular interests, objectives and capabilities? The paper further argues that, in contradistinction to much of the literature that presents an increasingly autonomous (traditional) private banking infrastructure, the corporate (non-bank) structure is also expanding its banking activities. This could be a contributory factor to the current systemic vulnerability in the banking system (Mouatt 2008). It is concluded that these developments are consistent with Marx's notion (p.468) of the gradual subjugation of finance capital by industrial forces, as the capitalist mode of production evolves, and the (Marx/Miliband) notion of the development and perpetuation of plutocratic elites (Miliband 1969; Marx 1971).

Indeed, Marx's theories on money, and his notion of the nature of the state, offer considerable explanatory power in the light of recent developments in the global financial system. 


\section{FINANCIAL POWER}

The rationale for this (paper) discussion is that whilst money is often seen as significant in studies of political economy, it is not often placed as the central mode of analysis. This is due, in part, to the mainstream view of money as relatively neutral in the long-term. If money is neutral and, by implication, the real economy is akin to a barter economy, then money merely facilitates a more efficient operation of the economic system. Conversely a variety of heterodox economists view money as non-neutral and having a wider scope of function. From this perspective the control of financial resources is a primary source of social power in a monetary economy and, subsequently, the politics of money creation and function then become relevant and interesting areas of study.

Power per se can be perhaps described as the ability to get someone (or an entity) to do that which they would otherwise choose not to do. ${ }^{1}$ Using this definition authors have then observed the exercise of power, in the present capitalist order, and surmised on the sources of this power (Mann 1986; Strange 1988; Walter 1993; Strange 1997; Ferguson 2002; Zarlenga 2002). Arguably the control of money and finance (including the provision and expansion of credit) constitute a primary (but not exclusive) source of this social power and therefore (arguably) needs to be the central mode of analysis. ${ }^{2}$ A corollary of this proposition could be that the control of financial resources largely determines power relations, or that shifting power relations (derived from other sources) are manifested through the medium of the control of financial resources. It is this definition of financial power, derived from Susan Strange, which has been adopted and forms the rationale for the whole paper (Strange 1988). Financial power is, at first, located in the ability to issue currency and control its exchange (forex) value, and is derived from the state and market in varying proportions (Strange 1988).

Money performs certain standard functions in the social economy, such as a means of account, store of value, enabler of exchange and a means of deferred payment. This functionality, in turn, needs a social acceptability that is derived from the (state) monetary authorities' ability to maintain scarcity, legitimacy and stable inflation. Yet, it is assumed that money is not neutral (in a Ricardian sense), where money simply enables the economy to operate, since financial powers are able to determine outcomes through the instigation (and regulation and cessation) of economic activity. This activity might otherwise not occur and may have a long-term impact. ${ }^{3}$ Furthermore, the quality of fungibility (the ability to change form) increases money's operational flexibility in relation to other assets or sources of power and endows it with commodity qualities. Indeed it is, arguably, indispensable to the exercise of virtually all power. The controllers of assets in other forms (including near-liquid assets) simply do not possess the same abilities despite their value. In order to exercise financial power, they would need to materialise it by transferring their assets into a money form. Similarly, social power derived from other sources is limited, without the access to and control of financial resources. Monetary control, therefore, must be obtained.

\footnotetext{
1 There are, of course, different modalities of power such as coercion, manipulation, seduction or authority as well as spatial and time complexities in the exercise of power Allen, J. (2003). Lost Geographies of Power. Bodmin, Blackwell.

${ }^{2}$ Money is defined here as state produced fiat money, in note and coin form, in combination with legallysanctioned credit monies in sight deposits.

${ }^{3}$ This notion assumes that money (and monetary factors) is the catalyst for productive agents rather than the entity that merely enables economic activity, following instigation by production agents.
} 
The control of money is, of course, exercised through the possession of financial resources (in conjunction with associate property rights) or the control and management of the institutions and systems that determine its use. Financial power thus wielded can then manifest in the real global economy in a variety of modes through inter alia its (spending power) impact on global markets, new economic activity, war finance, international capital flows (and their ramifications) and the social relations between creditor and debtor. It is these social power capabilities that enable those that wield financial resources to pursue an extremely wide range of objectives and strategies in almost every aspect of life. Furthermore, the initial money-issue (and maintenance of exchange value) gives those that preside over the function, substantial social power.

Credit creation, for instance, is a key source of financial power as a direct consequence of the pervasive use (and ubiquity) of credit-money. Credit has enabled economic systems to evolve more efficiently through the recycling of money surpluses to deficit agents. Yet, in the present era, levels of debt have reached unprecedented volumes and substantial political leverage is transferred to the creditors. ${ }^{4}$ Any principal and interest repayments required will also restrict the present spending power of borrowers and increase the financial power of lenders. Furthermore, the interest is sometimes compounded. The net effect is that as capitalism evolves there is an accumulation of the relative financial power of rentier creditors, since the credit expansion process itself leads to an expansion of their resources. Ironically, as credit expands there is not enough circulating money (if obliged to use the current stock) to meet all of the loan contract repayments plus the interest, a phenomena known amongst monetary reformers as the 'impossibility contract', and therefore capitalist development then relies upon further credit expansion (to supply sufficient quantity of circulating money) in order to function (Kennedy 1995). In addition, as a result of modern fractional backing as described by the endogenous money paradigm, money is created ex nihilo by the private banking infrastructure and does not require the pre-existence of funds prior to the lending contract (Hawtrey 1919; Naito 2008). In addition, even the necessary liquidity to meet capital adequacy requirements (legal and operational) does not have to preexist in order for lending to take place (Pettifor 2006; Rochon 2007). Also, the proportion of credit-money in circulation (in relation to fiat-money) has also increased in the modern era, rising from 50\% in 1945 to $97 \%$ in 2001 in the United Kingdom (Shakespeare 2002). This reflects, of course, a decline in state (financial) capability in terms of money-issue.

Credit creators can also grant or restrict spending power as well as 'manage or mismanage' currencies through the leverage they permit, which then affect consumer markets and fluctuating exchange-rates. Both activities lead to a redistribution of financial resources (Strange, 1988). Strange has explained how this financial power is located in a financial structure that consists of two elements. Firstly the systems of credit creation, determined jointly between the state and private banks (in varying proportions), and the processes that determine exchange-rates. These rates derive from state economic policies, inter-state negotiated regimes and (private) agent activity in the foreign exchange market. The nexus between state and market (a key paper theme) consequently becomes a key factor in determining the distribution of financial power. Yet, since the historical expansion of the state itself has coincided with its increasing indebtedness to the private banking structure, the

\footnotetext{
${ }^{4}$ The developed world, for instance, has subjugated the developing world to neo-liberal economics through the use of structural adjustment policies of the IMF/World Bank following widespread default Adams, N. (1993). World's Apart - The North/South Divide and the International System. Guildford, Zed.
} 
state could be viewed as the weaker partner in the relationship. This view, of course, necessarily implies the existence of a bourgeois state (following Miliband), that prioritises the protection of the private ownership of capital in its many (including money) forms. Any reforming forces in the state have, in the main, been reluctant to challenge this.

Financial powers are also instrumental in impacting capital flows where, in recent years, international transactions have grown exponentially (Griffith-Jones 1998). These private capital flows enhance exchange rate risk and enforce a monetary discipline on those states that are able to manipulate their macroeconomic variables enough in order to further their economic interests. Those states that are not capable find that currency devaluations lead to repressive adjustment policies and an enforced exposure to foreign direct investment that enables multinationals to purchase assets 'on the cheap'. ${ }^{5}$ State sovereignty is subsequently reduced as the capability of financial power is increased (Strange 1988).

Financial power is also manifested through the use of international money. The US dollar, as the main reserve and vehicle currency, fulfils this role and US financial powers gain substantial seigniorage, notwithstanding periodic difficulties in practice. ${ }^{6}$ General confidence in the dollar, imperative for international liquidity, can be maintained with both long-term balance of payments equilibria and prudent monetary management. Yet the nature of international money is such that all currencies (including the reserve) are ultimately valued, in 'forex' markets, that operate (it is assumed) according to the relative strengths of underlying fundamentals. This overall currency competition, as Cohen notes, subsequently leads to a redistribution of inter-state (or currency area) financial power and is therefore significant for the future world order (Cohen 1998).

Also, multilateral monetary regimes such as Bretton Woods, as sets of political arrangements that define the structure of the international financial system and regulate the processes, can restrict the fungibility of money and financial power is subsequently curtailed. Exchange rate regimes, for instance, seek to maintain currency stability amongst trading partners, which is useful for sustaining trade but may necessitate capital controls. Whilst these serve state development agendas the capabilities of inter-state private financial powers are restricted. Conversely, during the neo-liberal order, rate flexibility has become increasingly pervasive and private financial power is, therefore, then increased through global capital movement. In the same manner, of course, the various government legal and operational influences, on respective national financial systems, will also further impact the functioning of money.

As stated, the underlying assumption of the paper is that the private control of monies is increasing at the expense of the state with presumed ramifications for (financial) power relations. Several writers have observed these developments in the present era of capital flow liberalisation, financial market deregulation and private credit creation (Helleiner 1994; Killick 1995; Strange 1996; Cohen 1998; Griffith-Jones 1998). Still other authors have emphasised the strong role of political (state and non-state) factors driving these changes (Helleiner 1994; Cerny 1998; Germain 1998). Since the collapse of Bretton Woods, hedge

\footnotetext{
5 The Asian crisis of 1997 was an example of such a currency crisis.

${ }^{6}$ The Triffin paradox points out that in order to ensure liquidity an international reserve currency needs be plentiful and the host currency needs to run a balance of payments deficit yet, conversely, in order to maintain stability and confidence in the international money a surplus (or at least sustained equilibria) needs to be obtained Triffin, R. (1960). Gold and the Dollar Crisis. New Haven, Yale University Press.
} 
funds, currency speculators (and short-sellers), investment banks and private equity firms have all increased their activities in the global financial markets where there is now an enhanced incentive (and hence temptation) to manipulate market values. These developments, arguably, serve to undermine the capabilities of the state and the level of cooperation in the international state system.

A further (implicit) assumption is that a relative accumulation of money resources, presumably by private financial 'rentiers', contributes to a de facto redistribution of 'financial power' towards a monied elite. The elite, in turn, consisting of both non-bank corporate and financial entities, forms a plutocratic elite. Antecedents of these notions can be found in Lenin, Luxemburg and Hilferding, following the rise of the joint-stock company and, in more recent times, by several academics and monetary reformers (Hilferding 1910; Luxemburg 1971; Kennedy 1995; Lenin 1996; Shakespeare 2002; El Diwany 2003). Through the combination of the role of interest (and fees and charges), speculation, accumulation and the control of money issue, state capability is subsequently eroded to the potential detriment of the productive economy and society. In addition to the accumulation of monies, there is also the impact of increasing centralisation (particularly in crisis) of corporate and financial entities, leading to a further concentration of financial power. As Marx noted:

"Talk about centralization! The credit system, which has its focal point in the allegedly national banks and the big money-lenders and usurers that surround them, is one enormous centralization and gives this class of parasites a fabulous power not only to decimate the industrial capitalists periodically but also to interfere in actual production in the most dangerous manner - and this crew know nothing of production and have nothing at all to do with it" (p. 678)

(Marx 1981).

In the Hilferding notion of finance capital, for instance, (investment) banks are seen as integrated with (increasingly concentrated) joint-stock firms with the financiers driving the process. Meanwhile the state functions merely as an extension of the bourgeois corporate and financial interests (Hilferding 1910; Miliband 1969). In an earlier paper, the author challenged this Hilferding view on the grounds that, in the modern era, finance had become more autonomous from production. It had appeared that whilst corporate and financial entities had similar interests most of the time, there were periods of divergence and, financial powers were able to determine outcomes as they wished (Mouatt 2005). Yet, there are contemporary signs of weakness in the private banking infrastructure. Banks now earn a smaller proportion of their profit from interest and they are increasingly exposed to the vagaries of international financial markets, through their own exposure to trading positions. In addition the corporations are less dependent on bankers for capital, as a consequence of retained profits, and firms are also further developing their own monies and banks. The information revolution has further facilitated these developments and assisted in the creation of new (money) circulation channels. This emerging corporafinance system (my terminology) could have the potential to gradually replace the current financial system, as corporate processes encroach upon and replace traditional banking activities. There has also been the recent imperative for the state to provide liquidity to banks that are technically insolvent, as their liabilities exceed their assets, as a result of the devaluation of any (toxic) collateralised debt securities they are holding and the cessation of inter-bank lending. It is within this context, that a possible corporafinance system is emerging. 


\section{THE FINANCIAL STATE}

The Marxist (class) conception of the state, following Marx, is that it simply represents an extension of the interests of capital (Miliband 1977). This has been theorized from the perspective of earlier competitive capitalism and, the more recent, monopoly capitalist (high degree of market concentration) form (Miliband 1969; Poulantzas 1974). These interests of the capitalist class can be considered to be inter alia the protection of private property (in terms of the means of production), a business legal infrastructure, state-supported (capitalist) banking, free markets, minimal regulation and competition law. If we examine the historical activities of the state in western civilization, over the last five centuries, it is difficult to convincingly argue that these core capitalist essentials have been under serious threat at any point. Furthermore, as Kliman has recently argued, the state is often involved in direct action to protect the system from crisis or collapse in what has been termed 'state capitalism' (Kliman 2008). ${ }^{7}$ Be that as it may, the Marxist view can be separated into two distinct viewpoints, even though they amount to the same political outcome. The first, associated with the ideas of Nicos Poulantzas and Goran Therborn et al, identifies a political structure where the institutional entities that constitute the state are clearly formed from class relations per se (Barrow 1993). The second viewpoint, conversely, suggests that the political process has a power balance, at any particular point in time, which is consistently biased towards maintaining the (key) interests of the capitalist class (Olin-Wright 2002). The Marxist notion of the state is normally challenged with reference to the liberal democratic state that is presented as having a pluralist nature. The state is seen as autonomous from the interests of private capital (or any other interested party) and operates in the midst of (and consists of) a disparate plurality of powers e.g. business, banks, societal groups, external forces etc (Ball 1977). It is in the political process that this power mélange determines outcomes. Yet, this (arguably) does not detract from the empirical reality which, appears to demonstrate that the key interests of capital have remained unchallenged (in any serious way) in the modern era.

It is also appropriate to consider the modern state within the context of globalization. One of the consequences of a crude view of power, as a possessed capability, is the emphasis that this gives to the international society (and their comparison) of states. Later Marxist thinkers, however, have developed ideas that have pointed towards an alternative view. The approach of Gramscian Robert Cox, for instance, enables a much broader concept of world order, which takes account of the international dimension, and is concerned about power relations at varying levels instead. Cox focuses on 'classes' rather than states whose condition (in a Marxian sense) is determined by their material relations in the (now global) production structure. Since the production structure creates the resources that are indispensable to other sources of power (e.g. military power) the relations (hierarchies) of production are responsible for forming the political authority - the state (Cox 1987). The state, in turn, reinforces the (same) political hierarchies of production that galvanize a 'system of accumulation'. In this sense power and wealth are accumulated by the 'exploitation' of some groups over others - at a global level (Strange 1996). ${ }^{8}$

The state has clearly discharged different functions in the monetary system, depending on historic context and place, a notion that is central to this study. Karl Polanyi, for instance, had pointed out that power (including financial) ebbed and flowed between state and market,

\footnotetext{
7 Andrew Kiman attributes the term 'state capitalism' to Ray Dunayevskaya.

${ }^{8}$ These ideas are similar to the ideas of the French 'regulationist' school Lipietz, A. (1983). The Enchanted World - Inflation, Credit and the World Crisis. Thetford, Verso.
} 
depending on the historical epoch in question (Polanyi 1944). So, how is financial control actually discharged by the modern capitalist state as (commonly) determined by the professional, academic and informed (popular) sources? Clearly, as Knapp had noted in a 1905 seminal work, the authorities are responsible for the sanctioning of the currency (by law) which, in turn, finds its legitimacy in its acceptability for the payment of state taxes (Knapp 1924). Yet, the urban myth that suggests it is the government that solely issues the currency is simply not true. So, if this is the case, what does the banking, and educational literature, say on the matter?

There are, of course, exogenous and endogenous explanations of money-creation. Yet, in reality, it is a combination of the state (including the national bank as an agency) in conjunction with the private banking infrastructure that is responsible for the money-issue. One of the common difficulties is that the economics literature (e.g. Pilbeam) tends to present the credit multiplier, as a demonstration of (private bank) money expansion, which necessarily depends upon the existence of a (state determined) reserve asset ratio (Pilbeam 2005). Yet, as Rochon has noted, this ratio has disappeared in a few western states (including the UK), and is minimal in others. This continued inaccuracy gives the impression that the state is still able to influence the overall level of (credit) money expansion. There is a real need, therefore, for the textbooks to be rewritten (Rochon 2007). A notable exception is the Howells and Bain textbook. Here there is an explanation (primarily for undergraduates) of the endogenous money paradigm, with reference to double-entry book-keeping, termed the 'flow of funds' model since money is created in response to demand. The authors also note that the unreality of the alternative (monetary base) multiplier model still persists in many educational explanations (Howells 2002). Be that as it may, since the state (or central bank) sets the shortterm interest rate, in an exogenous sense, it could still be argued that (depending on definition) they are still responsible for the overall level of monies created. Yet, this is ineffectual since they are not able to have accurate knowledge of the likely credit consumer behavior and, therefore, no reliable indicator of the overall volume of credit money that will be established. The flow of funds model recognizes that money comes into being as a result of loans and, establishes a corresponding liability and asset. The deposit once created becomes a bank liability, and the loan itself forms an asset, since the principal (plus interest) needs to be repaid to the bank. The significant point here is that the bank has not lent preexisting funds (as is commonly thought) but represents a fresh money-issue in the form of an accounting entry. The money has been created ex nihilo and then circulates as electronic bank account money until the loan is repaid. In the language of the French/Italian circuitists, this represents the creation and destruction of money (Gnos 2004). In this sense, money needs to be viewed as a flow rather than a stock. The balance sheets of the commercial banks will consist, therefore, of various assets and liabilities that are subject to any legal monitoring and audit that the modern state devises. The bank ratios of reserves (liquid assets) to their loan portfolios will necessarily change, of course, as new lending takes place and deposits are drawn upon.

There is some debate, however, between the structuralist and horizontalist view of endogenous money-issue, in response to demand at the government determined (or independent central bank) short-term interest rate. In the horizontalist conception, the private banks expand credit completely in response to demand at a horizontal supply, whereas in the structuralist notion it is suggested that the banks require higher interest rates (compensation) at larger volumes of credit expansion (Wray 2004). Be that as it may, it is assumed in both of these viewpoints that the government (or delegated agency) sets the interest rate with regard to prevailing priorities. Yet, as Wray notes, even an exogenous interest rate has a measure of 
endogenous determination since, the policy-makers are responding to certain factors derived from the market (Wray 2004). In addition, the state has relinquished responsibility for LIBOR in the current UK system, where short-term (often overnight) inter-bank lending is determined by a consortium of big banks, notwithstanding some state-influence (from central bank open market operations), and private banks set their own rates for lending, albeit in a competitive financial market (Ackrill 2001). Meanwhile, the central (or national) bank operates amongst the commercial bank network and, provides their daily need for reserves as required. However, this requirement is usually satisfied through inter-bank lending these days (Pettifor 2006). So, according to the informed consensus, money is issued as debt (creditmoney) in response to consumer demand at a given short-term interest rate, regardless of who determines the level.

According to a widely distributed textbook, the government, via the central bank, can determine (or influence) the money supply through three methods (Pilbeam 2005). Firstly, by the buying and selling of treasury securities, known as open market operations, which then has a bearing on the LIBOR rate and, in turn, general lending. Yet, as Howells outlines (p.260), the overall determination of the money supply is not what the bank hopes to achieve when they engage in this activity in practice (Howells 2008). Secondly, by changing the reserve asset ratio the state can restrict or loosen any credit expansion, through the credit multiplier. However, since the reserve asset ratio no longer exists in the UK, multiplier explanations are fallacious. Thirdly, through the central lending rate and its impact on general lending (Pilbeam 2005). Yet, private rates are only 'loosely' based on the national bank (Bank of England monetary policy committee) rates. Notwithstanding, there have been times when there has been a serious attempt, from the state, to monitor and determine the nominal amount of monetary growth but, this has led to substantial difficulties in practice. During the 1970's, for instance, the 'corset' (special compulsory non-interest deposits at the Bank of England in order to restrict credit expansion), cash ratios, (strictly observed) reserve asset ratios and direct credit controls were used by successive governments until finally abandoned in 1980. Most of these methods relied on monetary base control, the use of the level of liquid assets that banks have in relation to their overall lending, and this proved to be problematic (Howells 2008). Firstly, when the state used to target the monetary base (MB) it often meant fluctuations in short-term interest rates, which led to undesirable macroeconomic instabilities. Secondly, since the MB is a liability of the central bank it can cause problems for the bank officials because, they do not always know what volumes they will need in their 'lender of last resort' capacity (to the private banks or the government). They tend to prefer more certainty in their own balance sheets in practice. Thirdly, even if the central bank knew exactly how to respond to reserve needs (e.g. through a precise value of bond-issue), they are not practically able to always respond at will to the relevant MB needs. It was these types of time lags inter alia that led the Thatcher administration to abandon monetary targets in the early 1980's. Fourthly, in some financial systems, there would need to be structural changes to the private banking system. In the UK, for instance, the clearing banks have overdraft facilities with one another, making it more difficult for the central bank to implement $\mathrm{MB}$ control by measuring private bank reserves. Fifthly, most of the assets of a typical bank consist of their non-marketable loan portfolio. It is not always possible for commercial banks to respond to reserve asset ratios, for instance, since they cannot simply just sell parts of their non-liquid outstanding loan contracts. Sixthly, private bank reserves pay no interest which, amounts to a tax on banks and this then leads to an increase in their spread (between deposit and lending rates) and, perhaps, a detrimental impact on the general economy. Finally, the 'lender of the last resort' facility might be compromised when (even solvent) banks require reserves during times of tight $\mathrm{MB}$ control. Would the central bank still be able to offer 
convertibility in these circumstances? If they do not, the stability of the entire system is undermined. So, as MB control was abandoned by the state, the financial power of private banks has been increased.

\section{THE INTERNATIONAL FINANCIAL SYSTEM}

In the absence of global government, historic monetary cooperation has relied upon interstate negotiation and trust. During the historical periods that gold and silver (or convertible paper) were accepted as international money, global trade could be expanded (beyond that of barter) since the commodity-money transcended the financial boundaries of the nation-state. The gold standard, for instance, had also benefited from the size and reach of the Pax Britannica, since confidence in the pound was instilled as a consequence of British international activity. In the modern era, exchange rate regimes such as the Bretton Woods (BW) system, or the European Exchange Rate Mechanism (ERM), have involved substantial collaboration and had (as already stated) significant implications for the monetary sovereignty of nation-states. During the BW fixed exchange rate system, for example, backed by central bank dollar to gold convertibility (at $\$ 35$ per oz), capital controls were used to engender balance of payments equilibrium (by virtually eliminating private speculation) and member countries were expected to 'adjust' their macroeconomic conditions to ensure trade compliance. Monetary policy instruments (including open market operations), and occasional IMF lending, were needed to guide states towards this purpose. Yet, it was the reluctance of (current account) surplus countries to inflate, particularly Japan and Germany, which was one of the principal causes of the breakdown of the system in the seventies. When this factor was combined with the devaluation of the dollar, and oil price shocks, the BW system collapsed. During its operation, nation-states had needed to ensure that monetary policy adhered to the necessary conditions for trade stability. The early period of the ERM (from 1979 to 1986) had also involved capital controls and, member states were restricted in their monetary sovereignty in the same manner. This erosion of (state) financial management was further accentuated when exchange controls were removed in 1986, as part of the Single European Act, and countries needed to maintain market risk premiums (in practice an interest rate above the strong Deutschmark) in order to prevent speculative attack and a breakdown of the system. Interestingly, Potts had convincingly argued that, as a consequence, there would be more monetary sovereignty for the UK (or any other member state) in the Euro currency than could exist whilst in the ERM (Potts 1997). The increased currency speculation has also, of course, served to erode the monetary sovereignty of nation-states in recent times, because individual treasuries simply do not have enough funds to conduct effective open market operations in comparison with colossal privately owned volumes. ${ }^{9}$ This point was highlighted by Griffith-Jones in her research work on capital flows (Griffith-Jones 1998). Some critics have subsequently called for a 'Tobin' tax to deter speculation and mitigate these harmful effects - restoring a measure of sovereignty (Tobin 1978). Other forms of monetary regulation, however, which are a direct result of international cooperation, are likely to have a mitigating impact on monetary sovereignty. The BIS Basle accords for instance, particularly the 2000 (Basle 2) agreement, has led to the de facto reduction of state regulatory power (as stated government reserve requirements have virtually disappeared) and contributed towards the 2008 financial crisis as a direct result of the greater self-regulation of security risk assessment. This has led to more 'in-house' risk assessment and occasional conflicts of interest between financial agents (Pettifor 2006; Rochon 2007; Docherty 2008; Rafeeq 2008).

\footnotetext{
${ }^{9}$ Currency 'short-sellers' exacerbate these problems for modern national banks.
} 
A further issue is that, in the post war era, the use of the US dollar, as the main reserve currency, has meant that other nation-state financial authorities have been, to a greater or lesser extent, impacted by the vagaries of US domestic monetary policy. The US dollar is used as the denomination for multinational accounting, statistical measures, global commodity exchanges (including the increasingly tense oil trading platforms), multilateral institutions, capital markets, sovereign lending, commercial credit and as a vehicle currency for virtually all foreign exchange transactions. Fluctuations in the dollar exchange rate, and general (reserve) currency demand and supply conditions, therefore have a substantial impact on the global economy. Nation-states have found, in addition, that there are implications for their monetary sovereignty. Benjamin Cohen, in his research work, has identified that, as a consequence, there is a measure of inter-state competition in order to harness the benefits that accrue to a nation-state when their currency is in general use - such as cheaper borrowing and the US has certainly gained in this respect in the modern era (Cohen 1998). In a world of hard and soft currencies (and fewer currencies), of course, the evolution of global monies is a constant activity with ramifications for sovereignty as financial power is eroded or enhanced.

\section{THE INFORMATION REVOLUTION AND CORPORAFINANCE}

States have clearly experienced an erosion of (financial) sovereignty in the modern era and private banks and economic agents, as well as non-financial corporates, have experienced an increase in capability. Yet, are there changes in the (financial) power relations between nonbanks and traditional banks? This paper argues that non-banks, as previously stated, are encroaching on the core activities of the traditional banking sector in their search for profit. Even if we reject the Marxian capitalist trajectory, where firms seek to realize more surplus value to offset the falling rate of profit (in labour terms), profit maximization is generally accepted as a corporate imperative. In this sense, financial sector changes reflect the normal capitalist modus operandi and we can expect the bourgeois (Miliband) state to support such developments. This presents fresh challenges for firms, of course, since the IT revolution and innovation have led to new channels of financial circulation, and (financial) liberalization has also contributed towards a more (competitive) global economy. The companies most likely to succeed, as Lietaer noted, are the ones most able to combine electronic knowledge systems with production. If this is extended to the development of corporate monies, banks and payment systems this will further strengthen their competitive position (Lietaer 2001). So nonbanks, studies reveal, are playing increasingly significant roles in the financial world (ECB/FRBKC 2007; Adams 2008). Bradford et al have also examined their varied roles in payment activity, in both traditional and emerging systems. As a consequence they have complex relations with the traditional banks and payment system users. In addition, since they are rarely directly involved with final settlements they appear, at least, to be less associated with systemic risk. In reality, however, both banks and nonbanks are susceptible to operational risk factors (Bradford T. 2002).

Another feature of the new financial landscape is that retailers have diversified into financial services, challenging banks in their own core markets. ${ }^{10}$ Since retailers have strong brands

\footnotetext{
10 The retail sector is not the only threat to the retail banking and financial sectors. Car manufacturers, for instance, have found that the development of finance houses, for car credit, has been an anecdote to tighter margins in recent years. GM capital provides another example of multinational corporate finance houses Houghton-Budd, C. (2005). Auditorial Central Banking - Monetary Themes for the 21st Century. New Economy Publications: Centre for Associative Economics.
} 
and customer responsiveness, they often have stronger market knowledge. Yet, as Welch and Worthington have identified, retailers have so far adopted a selective approach to the provision of financial services and do not cover the wider range offered by banks (Welch 2007). Notwithstanding, the retailer threat to retail banking is likely to continue. Retailers have strong customer relations, provide services and tie in customers with reward schemes. Conversely, the banking trend has been towards ATMs and 'distance banking', driven by cost-saving motives, and bank-customers rarely get to see banking personnel. In contrast, retail customers regularly visit their preferred retailer for weekly shopping or for a variety of other goods such as medicines, mobile phones, kitchen items, white goods, electronics goods, books and CDs. Much financial innovation by nonbanks, therefore, has been driven by this closer customer interaction. A recent report concluded that the new entrant retail players did pose a serious threat for the long term, though the inroads made by retailers (at the time) into the financial sector was limited (Lascelles 1999). It seems the corporate sector is poised to make a serious impact on the retail banking sector, and its financial systems, facilitated by technology-led innovations, in a similar manner (perhaps) to that predicted by Marx.

Marx had posited that the real power in society was located in industrial capital, since this was where value was created, and he viewed social interaction as determined by the material relations of production. This is reflected in his view of the emerging capitalist credit system:

"The commercial and interest-bearing forms of capital are older than industrial capital, which, in the capitalist mode of production, is the basic form of the capital relations dominating bourgeois society - and all other forms are only derived from it or secondary: derived as is the case with interest-bearing capital; secondary means that the capital fulfils a special function (which belongs to the circulation process) as for instance commercial capital. In the course of its evolution, industrial capital must therefore subjugate those forms and transform them into special functions of itself" (Marx, p.468)

Interest-bearing capital, of course, is loaned (by the owners) at interest to industrial capitalists and therefore depends upon the production plans taking place. Marx further argued that, as capitalism developed, the subjugation of this capital form results from two processes. First, the 'violence' of the (bourgeois) state would lead to the enforcement of lower interest rates, to the benefit of industrial capitalists who then gain a larger proportion of surplus value. ${ }^{11}$ Secondly, the subjugation derives from the emerging (bourgeois) credit system that, Marx sees as a purposeful creation of the capitalist mode of production, in order to gain the surplus value traditionally extracted by the usurers (Marx 1971). He further predicts this credit system evolving as the scale of manufacture increases. The banking industry indeed experienced a major transformation, throughout the industrial revolution, and new financial structures were (arguably) one of the main drivers. Deane, for instance, explored the role of the banks during this time and concluded that the emergent banking structures enabled capital to be raised, to fund the development of factories, and provided a means to save and reinvest accumulated wealth (Deane 1988). Similarly, the information revolution is resulting in its own set of changes to monetary structures, to meet the needs of the emergent electronic and virtual interactions. As new forms of banks and money became the main industrial revolution driver, the emergent financial structures are likely to be a cornerstone of the information age.

\footnotetext{
${ }^{11}$ However Marx sees this as pertaining to a 'lesser-developed' capitalist economy Marx, K. (1971). Theories of Surplus Value: Part Three. Moscow, Progress.
} 
Marx also explained how commercial capital would be subjugated, as the merchant (of the Middle Ages) became transformed into the industrial capitalist. In the former instance, the merchant (and commercial capital) had dominion over the 'producing' guilds, or peasant craftsman, since they chose (or not) to purchase their wares. In the latter scenario, the producer is himself the merchant and commercial capital becomes simply an "intermediary only in the circulation process" and therefore more subject to the industrial capitalist (Marx 1971). This process, of course, became even more apparent as large-scale production emerges, since the market power of the firm is enhanced. So, Marx had illustrated how the natural evolution of the capitalist mode of production, driven by the needs of industrial capital (and the bourgeois state), would lead to a gradual transformation of the financial system. The Marx approach to crises, also, is also worthy of consideration at this time.

\section{FICTITIOUS CAPITAL AND CRISES}

It was stated that (for Marx) money mediates the exchange of commodities and also, its circulation allows hoards of money-capital to become established. In this instance, Say's law fails to hold in the real world and, crises ensue as commodities fail to sell in sufficient quantities with various capitals experiencing losses (Bottomore 1991). ${ }^{12}$ In addition, within these crises, hoarding can represent an unwillingness of capitalists to advance further money when faced with the prospect of further shortfalls of demand in markets if (prospective) commodities are produced and enter circulation (Bottomore 1991). A further inhibitor to the advancement of monies as capital, from funds held in reserve, is the tendency for the rate of profit (in labour terms) to fall (LTFRP). The validity of the LTFRP has been convincingly restored, since the eighties, by the work of the Temporal single system interpretation (TSSI) school (Carchedi 1996; Freeman 1996; Kliman 2007). In all of these circumstances mentioned, capital can be tempted to migrate towards fictitious capital in the financial markets, induced by the prospects (for some) of greater returns. Yet, since the very existence of fictitious capital (nominal value in excess of the underlying abstract labour-time value) amounts to a zero-sum game, the activity can be precarious for agents and simply constitutes a (re)distribution of current nominal money (and hence social power) stocks. Those that gain, therefore, do so at the expense of others and no (surplus) value has been created in the process. In addition, demand and supply conditions, associated with this capital migration, directly facilitate the creation of speculative asset 'bubbles' and the subsequent crises that follow. Stable expectations of asset appreciation, as Kregel notes, then contribute to the 'bubbles' as a result of rational behaviour (profit maximisation), rather than a psychological deficiency on behalf of the market participants (Kregel 2008). If greater margins were being achieved in the productive economy, circumstances would (arguably) be different.

Marx had further posited that during an upturn in the trade cycle, there will be an expansion of credit (in terms of financial capital) and capital advanced from hoards, whilst the reduced expectations of capitalists during a downturn would lead to a contraction of credit and capital advanced (Marx 1981). A severe contraction of credit (like the present credit 'squeeze') would inevitably lead to a crisis. In this instance, the physical quantity of monies in circulation (in a virtual pure credit-money economy) is insufficient to purchase total output as well as meet interest payments (and thus Say's law does not hold), unless there is an

\footnotetext{
${ }^{12}$ A further consequence of crises is, of course, the concentration of capitals as resources are reallocated towards centralising firms from those experiencing liquidation and foreclosure.
} 
expansion of credit. A credit squeeze, therefore, leads to the inevitability of default and unsold stocks. Thus Marx, in addition to presenting an accurate prediction of the general (future) transformation of the financial system, has also provided a convincing explanation of the present financial predicament in the global economy.

\section{CONCLUSION}

This paper has argued that in the modern era, as a consequence of national and international systemic factors, the state has experienced an erosion of its financial capabilities in terms of money-issue, value and function. Many of the developments have followed, as Helleiner has convincingly posited, intensive lobbying from the private banks in the post-war era so that the neo liberal (financial) order cannot simply be passed off as a result of economic processes alone (Helleiner 1994). As a result of such developments, private agents and banks, as well as non-bank entities, have found their capabilities enhanced, which are then manifested in their exercise of (financial) social power in the modern financial system. Another significant conclusion is that non-banks are increasingly encroaching on the core business activities of the traditional private banking infrastructure which may, of course, partly explain the more precarious nature of traditional bank income-earning activities of late. It is further concluded that these phenomena have been adequately predicted by Marx in his theories of the LTFRP, capital migration and the subjugation of financial capital by industrial capital. The Miliband notion of the bourgeois state, of course, is seen as an extension of the interests of industrial capital and, therefore, complicit in the facilitation of these developments.

\section{REFERENCES}

Ackrill, M. H., Leslie (2001). Barclays: The Business of Banking 1690-1996. Cambridge, Cambridge University Press.

Adams, C. M., Simon (2008). "The Information Revolution, Corporafinance and Latent Grassroot Money Forms." Southampton Business School Discussion Paper Series.

Adams, N. (1993). World's Apart - The North/South Divide and the International System. Guildford, Zed.

Allen, J. (2003). Lost Geographies of Power. Bodmin, Blackwell.

Ball, A. (1977). Modern Politics and Government 2nd Edition. Hong Kong, Macmillan.

Barrow, C. (1993). Critical Theories of the State. Madison, University of WIsconsin.

Bottomore, T. (1991). A Dictionary of Marxist Thought: 2nd Edition. Bodmin, Blackwell.

Bradford T., D. M., and Weiner S.E (2002). Nonbanks in the Payments System. Payments System Research Working Paper PSR WP 02-02, Federal Reserve Bank of Kansas City.

Carchedi, G. (1996). Non-Equilbrium Market Prices. Marx and Non-Equilbrium Economics. A. Freeman, Carchedi, G. Cheltenham, Edward Elgar. 
Cerny, P. G. (1998). "Politicising International Finance." Millenium: Journal of International Studies 27(No 2).

Cohen, B. J. (1998). The Geography of Money. London, Cornell University Press.

Cox, R. (1987). Production, Power and World Order, Columbia University Press.

Deane, P. (1988). The First Industrial Revolution. Cambridge, Cambridge University Press.

Docherty, P. (2008). "Basel II and the Political Economy of Banking Regulation - Monetary Policy Interaction." International Journal of Political Economy 37(2): pp. 82-106.

ECB/FRBKC (2007). Nonbanks in the Payments System: European and US Perspectives. Proceedings of Nonbanks in the Payments System: Innovation, Competition and Risk. Santa $\mathrm{Fe}$, New Mexico, European Central Bank and the Federal Reserve Bank of Kansas City.

El Diwany, T. (2003). The Problem with Interest 2nd Ed. Birmingham, Kreatoc.

Ferguson, N. (2002). The Cash Nexus: Money and Politics in Modern History, 1700-2000. St Ives, Penguin.

Freeman, A. (1996). The Psychopathology of Walrasian Marxism. Marx and NonEquilibrium Economics. A. Freeman, Carchedi, G. Cheltenham, Edward Elgar.

Germain, R. D. (1998). The International Organisation of Credit: States and Global Finance in the World-Economy. Cambridge, Cambridge University Press.

Gnos, C. (2004). Circuit Theory as an Explanation of the Real World. Modern Theories of Money: The Nature and Role of Money in Capitalist Economies. L.-P. R. S. Rossi.

Griffith-Jones, S. (1998). Global Capital Flows. Chippenham, Macmillan.

Hawtrey, R. G. (1919). Currency and Credit. London, Longmans, Green \& Co.

Helleiner, E. (1994). States and the Re-emergence of Global Finance: From Bretton Woods to the 1990's, Cornell University Press.

Hilferding, R. (1910). Finance Capital, Routledge.

Houghton-Budd, C. (2005). Auditorial Central Banking - Monetary Themes for the 21st Century. New Economy Publications: Centre for Associative Economics.

Howells, P. B., Keith (2002). The Economics of Money, Banking and Finance: A European Text: 2nd Edition. Gosport, Prentice-Hall.

Howells, P. B., Keith (2008). Economics of Money, Banking and Finance: 4th Edition. Gosport, Pearson.

Kennedy, M. (1995). Inflation and Interest Free, New Society Publisher. 
Killick, T. (1995). The Flexible Economy. London, Routledge.

Kliman, A. (2007). Reclaiming Marx's Capital: A Refutation of the Myth of Inconsistency. United States, Lexington.

Kliman, A. (2008). Worse than They Want you to Think - A Marxist Analysis of the Economic Crisis. N. Space. New York City.

Knapp, G. F. (1924). The State Theory of Money. London, Macmillan.

Kregel, J. (2008). Using Minsky's Cushions of Safety to Understand the Sub-Prime Mortgage Crisis, Brunei Gallery: School of Oriental and African Studies.

Lascelles, D. (1999). Europe's New Banks: The "Non-Bank" Phenomenon. London, The Centre for the Study of Financial Innovation.

Lenin, V. (1996). Imperialism: The Highest Stage of Capitalism. Bristol, Pluto.

Lietaer, B. (2001). The Future of Money - Creating New Wealth, Work and a Wise World. Guildford, Random House.

Lipietz, A. (1983). The Enchanted World - Inflation, Credit and the World Crisis. Thetford, Verso.

Luxemburg, R. (1971). The Accumulation of Capital. London, Routledge.

Mann, M. (1986). Sources of Social Power: Volume One: A History of Power from the Beginning to $A D 1760$, Cambridge University Press.

Marx, K. (1971). Theories of Surplus Value: Part Three. Moscow, Progress.

Marx, K. (1981). Capital: Volume Three. Bungay, Penguin.

Miliband, R. (1969). The State in Capitalist Society: An Analysis of the Western System of Power. Aylesbury, Quartet.

Miliband, R. (1977). Marxism and Politics. Oxford, Oxford University Press.

Mouatt, S. (2005). Global Financial Power, Capitalist Crisis and Uneven Development. Association of Heterodox Economics: Annual Conference, Leeds University.

Mouatt, S. A., Carl (2008). "Marx, Subjugated Banking and an Emerging Corporate Monetary System." Southampton Business School Discussion Paper Series.

Naito, A. (2008). Money, Credit and the State: Post Keynesian Theory of Credit Money and Chartalism. Association of Heterodox Economics Annual Conference, Anglia Ruskin University: Cambridge.

Olin-Wright, E. (2002). Seminar on Theories of the State. Madison, University of Wisconsin. 
Pettifor, A. (2006). The Coming First World Debt Crisis. Chippenham, Palgrave, Macmillan.

Pilbeam, K. (2005). Finance and Financial Markets:2nd Edition. China,

Palgrave:Macmillan.

Polanyi, K. (1944). The Great Transformation. New York, Octagon Books.

Potts, N. (1997). "National Economic Sovereignty and the Single European Currency."

European Review(January).

Poulantzas, N. (1974). Classes in Contemporary Capitalism. Thetford, Verso.

Rafeeq, M. (2008). Instant Experts - Dilute to Taste, Latticework Management Consultancy.

Rochon, L.-P. R., Sergio (2007). "Monetary Policy without Reserve Requirements: Central Bank Money as a Means of Final Payment on the Inter-Bank Market." CEMF Conference "Post-Keynesian Principles of Economic Policy" University of Burgundy, Dijon, December.

Shakespeare, R. C., Peter (2002). Seven Steps to Justice. Chippenham, New European Publications.

Strange, S. (1988). States and Markets. London, Pinter.

Strange, S. (1996). The Retreat of the State - The Diffusion of Power in the World Economy. Cambridge, Cambridge University Press.

Strange, S. (1997). Casino Capitalism. Manchester, Manchester University Press.

Tobin, J. (1978). "A Proposal for International Monetary Reform." Eastern Economic Journal 4: 153-9.

Triffin, R. (1960). Gold and the Dollar Crisis. New Haven, Yale University Press.

Walter, A. (1993). World Power and World Money. Exeter, Harvester/Wheatsheaf.

Welch, P. W., S (2007). "Baning at the Checkout 2007-08: Evaluating the Provision of Financial Services by Retailers." Journal of Financial Services Marketing 2(3): 230-245.

Wray, L. R. (2004). When are Interest Rates Exogenous? Working Paper No.30, Jerome Levy Economics Institute.

Zarlenga, S. (2002). The Lost Science of Money - The Mythology of Money: The Story of Power. United States, The American Monetary Institute. 